\title{
PRODUCTION OF INULINASE FROM KLUYVEROMYCES MARXIANUS USING DAHLIA TUBER EXTRACT
}

\author{
Sumat Chand Jain, P.C. Jain, Naveen Kango*
}

Department of Applied Microbiology and Biotechnology, Dr. Hari Singh Gour University, Sagar, M.P. 470003, India.

\begin{abstract}
Various carbon sources were evaluated for production of inulinase by yeast, Kluyveromyces marxianus MTCC 3995. Highest inulinase activity was observed with Dahlia extract ( $\left.25.3 \mathrm{nkat} \mathrm{mL}^{-1}\right)$ as carbon source. The enzyme activity was 1.4 folds higher than that observed in media containing pure chicory inulin (17.8 nkat $\left.\mathrm{mL}^{-1}\right)$. The yeast showed good growth on a simple medium containing dahlia extract $(20 \% \mathrm{w} / \mathrm{v})$ and yeast extract $(2 \% \mathrm{w} / \mathrm{v})$ as carbon and nitrogen source respectively, in $96 \mathrm{~h}$. at $28^{\circ} \mathrm{C}$ and $120 \mathrm{rpm}$. Lowest inulinase yield (4.8 nkat $\left.\mathrm{mL}^{-1}\right)$ was seen in the medium containing glucose as C-source. Although varied inulinase levels were noticed on different C- sources, Inulinase: Sucrase (I/S) ratios were noticed to be similar. Among various protein sources tested, yeast extract was found to be the best source followed by beef extract $\left(17.9 \mathrm{nkat} \mathrm{mL}^{-1}\right)$ and peptone $\left(13.8 \mathrm{nkat} \mathrm{mL}^{-1}\right)$. The enzyme was optimally active at $\mathrm{pH}(4.0)$ and $50^{\circ} \mathrm{C}$. TLC analysis of end product revealed that inulinase hydrolyzed inulin exclusively into fructose. Results suggest that the dahlia extract induced exoinulinase synthesis in Kluyveromyces marxianus and can be utilized as a potential substrate for inulinase production.
\end{abstract}

Key words: Inulinase, dahlia, fructose, Kluyveromyces marxianus

\section{INTRODUCTION}

Microbial inulinases are important industrial enzymes, which are usually inducible and extracellular. A number of yeasts, filamentous fungi and some bacteria are reported to produce inulinases $(7,13)$. Inulinases are receiving increasing attention due to availability of relatively inexpensive and abundant renewable substrate (inulin) for the production of high fructose syrup. The production of fructose syrup from inulin or inulin rich materials is a major area of applications of inulinases. Fructose is emerging as a healthy and safe alternative sweetener than sucrose, which causes problems, related to corpulence, cariogenicity, atherosclerosis and diabetes (22). Conventional fructose production from starch needs at least three enzymatic steps involving $\alpha$-amylase, glucoamylase and glucose isomerase and yields only $45 \%$ fructose. In contrast, the complete hydrolysis of inulin by a single step using inulinase gives a yield of about 90-95\% fructose (24). Apart from being a low calorie sweetener, fructose is also used in the production of ethanol, acetone and butanol, gluconic acid, sorbitol and fructo-oligosaccharides etc. $(12,19)$. 
Industrial applications of this enzyme, however, would only be feasible if it were available in large quantities at a competitive price. Production of inulinase is affected by medium components and type of the organism used for fermentation. Various carbon sources like fructose, sucrose, purified inulin have been examined for production of this enzyme (22). To compensate the high cost of inulin various plant materials like Jerusalem artichoke, dahlia (Dahlia pinnata), chicory, kuth roots, etc. have also been used for the production of inulinases $(7,19)$. Influence of sucrose concentration and culture conditions ( $\mathrm{pH}$ and aeration rate) were studied on inulinase production by $K$. marxianus var. bulgaricus ATCC 16045 to obtain maximum yield of $15.29 \mathrm{U}$ $\mathrm{mL}^{-1}$ (2). More recently, optimization of agro-industrial medium comprised of sugarcane bagasse, molasses and Corn steep liqour has been attempted to maximize the production of inulinase upto $436 \mathrm{U} / g d s$ (9). Ethanol precipitation of $K$. marxianus inulinase extracted from SSF was optimized using central composite design. An enhanced activity yield percentage (168\%) suggested removal of enzyme inhibitors after precipitation (5). The stability and kinetic behavior of immobilized $K$. marxianus inulinase in aqueous-organic solvent, butyl acetate was studied. Immobilized enzyme was more stable towards $\mathrm{pH}$ change while its affinity was found to decrease with the increase in organic solvent (16).

Dahlia is a flowering plant of family asteraceae commonly grown for ornamental purpose. The tubers of dahlia contain about $12.5 \%$ of inulin as a storage polysaccharide (3). Among the microbial strains used for inulinase production, those of $K$. marxianus and A. niger are the most commonly used ones (6, 7,12 ). In the present study, production and properties of inulinase by $K$. marxianus MTCC 3995 were examined on various carbon sources including crude dahlia extract.

\section{MATERIALS AND METHODS}

\section{Microorganism}

The yeast Kluyveromyces marxianus MTCC 3995 was obtained from Microbial Type Culture Collection (MTCC),
Chandigarh, India. The culture was grown on wort agar at $28^{\circ} \mathrm{C}$ and maintained at $4{ }^{\circ} \mathrm{C}$ on the slants of the same media.

\section{Substrates and chemicals}

Inulin (from chicory), fructose, 3,5-dinitrosalicycilc acid and corn steep liquor were obtained from Sigma chemical co., U.S.A. Precoated silica gel plates $\mathrm{UV}_{254}$ were obtained from Merck, Germany. Wort agar and other chemicals were of analytical grade (Hi-media, India). Mature dahlia tubers were obtained from a local nursery.

\section{Preparation of dahlia extract}

$100 \mathrm{~g}$ of the tubercles were washed in running water and crushed in a blender with $500 \mathrm{~mL}$ of distilled water. The slurry obtained was allowed to stand for sedimentation of particulate matter. Afterwards, it was filtered through muslin cloth and the filtrate was used in media formulation.

\section{Enzyme production}

$50 \mathrm{~mL}$ of dahlia extract was supplemented with $2 \%(\mathrm{w} / \mathrm{v})$ yeast extract as nitrogen source and was used for inulinase production. Production media with pure inulin (chicory root, Sigma), sucrose, fructose and glucose as carbon sources were prepared using the following composition: yeast extract: 14.0 $\mathrm{g},\left(\mathrm{NH}_{4}\right)_{2} \mathrm{SO}_{4}: 2.1 \mathrm{~g}, \mathrm{MgSO}_{4} .7 \mathrm{H}_{2} \mathrm{O}: 0.3 \mathrm{~g}, \mathrm{CaCl}_{2} .2 \mathrm{H}_{2} \mathrm{O}: 0.3 \mathrm{~g}$, $\mathrm{FeSO}_{4} .7 \mathrm{H}_{2} \mathrm{O}: 0.5 \mathrm{~g}, \mathrm{KH}_{2} \mathrm{PO}_{4}: 10.0 \mathrm{~g}$ and carbon source: $20.0 \mathrm{~g}$ per liter ( $\mathrm{pH} 5.0)$. Erlenmeyer flasks $(150 \mathrm{~mL})$ containing 50 $\mathrm{mL}$ aliquots of medium were autoclaved $\left(20 \mathrm{~min}, 121^{\circ} \mathrm{C}\right)$ and incubated with two loops from 48 h old culture of $K$. marxianus. Flasks were incubated at $28^{\circ} \mathrm{C}$ on a rotary shaker (120 rpm). Flasks were withdrawn at regular interval of $24 \mathrm{~h}$ and clear culture filtrate was obtained by filtering the broth through Whatman filter paper no. 1. All the experiments were carried out in triplicate and mean values \pm SD are reported as results.

\section{Effect of nitrogen sources}

Effect of different nitrogen sources including peptone, 
beef extract, yeast extract, and corn steep liquor (organic $\mathrm{N}$ sources) and $\mathrm{NaNO}_{3}, \mathrm{KNO}_{3},\left(\mathrm{NH}_{4}\right)_{2} \mathrm{SO}_{4}$ and $\left(\mathrm{NH}_{4}\right) \mathrm{H}_{2} \mathrm{PO}_{4}$ (inorganic $\mathrm{N}$-sources) was studied by incorporating $2 \%(\mathrm{w} / \mathrm{v})$ of each $\mathrm{N}$ - source in dahlia extract medium.

\section{Enzyme assay}

$0.2 \mathrm{~mL}$ of appropriately diluted enzyme (culture filtrate) was added to $1.8 \mathrm{~mL}$ of inulin $(1 \% \mathrm{w} / \mathrm{v}$ dissolved in $200 \mathrm{mM}$ sodium acetate buffer, $\mathrm{pH} 5.0$ ) and incubated at $50^{\circ} \mathrm{C}$ for 30 min. After incubation, total reducing sugars liberated from inulin were measured by adding $3 \mathrm{~mL}$ DNS reagent and boiling in a water bath for $5 \mathrm{~min}$ (10). Samples were allowed to cool and their absorbance was read at $540 \mathrm{~nm}$. Invertase activity was measured using sucrose solution $(1 \% \mathrm{w} / \mathrm{v}$ dissolved in 200 $\mathrm{mM}$ sodium acetate buffer, $\mathrm{pH}$ 5.0). One nanokatal (nkat) of inulinase/invertase activity was defined as the amount of enzyme which produced 1nano mol of fructose/glucose per second under the assay conditions as described above.

\section{Effect of temperature and $\mathrm{pH}$ on inulinase activity}

Effect of temperature was determined by incubating 0.2 $\mathrm{mL}$ of suitably diluted enzyme and $1.8 \mathrm{~mL}$ of inulin $(1 \% \mathrm{w} / \mathrm{v}$ in $200 \mathrm{mM}$ sodium acetate buffer, $\mathrm{pH}$ 5.0) for $30 \mathrm{~min}$ at different temperatures. The effect of $\mathrm{pH}$ on inulinase activity was determined by incubating $0.1 \mathrm{~mL}$ of undiluted enzyme sample in $0.4 \mathrm{~mL}$ of appropriate buffers $(0.2 \mathrm{M}$ sodium acetate buffer: pH 4.0 and 5.0; 0.1 M phosphate buffer: $\mathrm{pH}$ 6.0, 7.0 and 8.0; $0.1 \mathrm{M}$ Tris- $\mathrm{HCl}$ buffer: $\mathrm{pH} 9.0)$. To this, $0.5 \mathrm{~mL}$ of inulin $(1 \%$ $\mathrm{w} / \mathrm{v}$ in distilled water) was added and the reaction mixture was incubated at $50^{\circ} \mathrm{C}$ for $30 \mathrm{~min}(6)$.

\section{Thin layer chromatography}

The end products of enzyme reaction were visualized using thin layer chromatography as described earlier (6). 200 $\mu \mathrm{L}$ of undiluted enzyme (culture filtrate) was added to $200 \mu \mathrm{L}$ of inulin (5\% w/v in $200 \mathrm{mM} \mathrm{NaAc}$ buffer, $\mathrm{pH} 5.0)$ and was incubated at $50^{\circ} \mathrm{C}$. Aliquots of $1 \mu \mathrm{L}$ were withdrawn after 30 min and spotted on TLC plate. Plates were developed with the solvent system containing isopropyl alcohol: ethyl acetate: water (2:2:1 by volume). Sugar spots were developed with reagent containing $0.5 \% \alpha$-naphthol and $5 \%$ conc. sulfuric acid in absolute ethanol and by heating the plate at $100^{\circ} \mathrm{C}$ for 10 min. Fructose and Raffinose were used as sugars standards.

\section{RESULTS AND DISCUSSION}

Among various substrates employed as carbon source for inulinase production, inulin-containing plant materials offer advantage in comparison to purified substrates in terms of lower cost and high productivity. Complex substrates from agro-industrial wastes have been of wider interest for production of microbial enzymes $(9,14)$. Root extract of a perennial herb, dandelion (Taraxacum officinale), has been reported as a competitive substrate for inulinase production by Aspergillus niger (6). Tubercles of yacon (Polymnia sanchifolia), also a member of Asteraceae, have been reported as an inexpensive substrate for inulinase production from Kluyveromyces marxianus (1) and garlic bulbs (Allium sativum) have been used for inulinase production from Streptomyces sp. (18). In the present study $K$. marxianus MTCC 3995 was able to utilize all the test C-sources for its growth. Growth on dahlia extract was maximum and a sharp decrease in turbidity of the medium was also noticed. Infusion prepared from tubers of dahlia was found

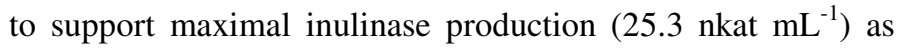
compared to pure inulin and other substrates (Figure 1). Dahlia extract has been reported to contain inulin $(3,21)$ and possibly this fructan component induced higher titres of inulinase. In the present study, compared to pure inulin as a carbon source, about 1.4-fold higher activity was obtained with dahlia. Cruz et al. (3) have also compared various carbon sources for inulinase production and obtained 1.26- fold higher activity with dahlia extract (3.68 $\left.\mathrm{U} \mathrm{mL}^{-1}\right)$ as compared to pure inulin $\left(2.92 \mathrm{U} \mathrm{mL}^{-}\right.$ $\left.{ }^{1}\right)$. Dahlia is an interesting alternative, since, it is a relatively 
cheap and easily available substrate, that can serve as a feedstock for large-scale fermentation, whereas pure inulin is only available in limited quantities and at very high cost. Singh et al. (21) have extracted raw inulin from dahlia tubers by processing at $15 \mathrm{Kg} \mathrm{cm}^{-2}$ for $10 \mathrm{~min}$. and used an optimized medium in a bioreactor to obtain $55.4 \mathrm{IU} \mathrm{mL}^{-1}$ in $60 \mathrm{~h}$ by an indigenous strain $K$. marxianus YS-1. Recently, Singh and Bhermi (20) have evaluated root tubers of Asparagus officinalis for production of exoinulinase by the same strain and have observed that enzyme yield (8.42 $\left.\mathrm{IU} \mathrm{mL}^{-1}\right)$ was three folds higher as compared to pure inulin $\left(2.7 \mathrm{IU} \mathrm{mL}^{-1}\right)$. Some of the recent reports of inulinase production and properties have used $2 \%(\mathrm{w} / \mathrm{v})$ sucrose as substrate for the assay of inulinase activity $(5,9,17)$. In comparison to these reports, we have also obtained higher activity towards sucrose $56 \mathrm{U} \mathrm{mL}^{-1}$ (945 nkat $\left.\mathrm{mL}^{-1}\right)$ and $52 \mathrm{U} \mathrm{mL}^{-1}\left(880\right.$ nkat $\left.\mathrm{mL}^{-1}\right)$.

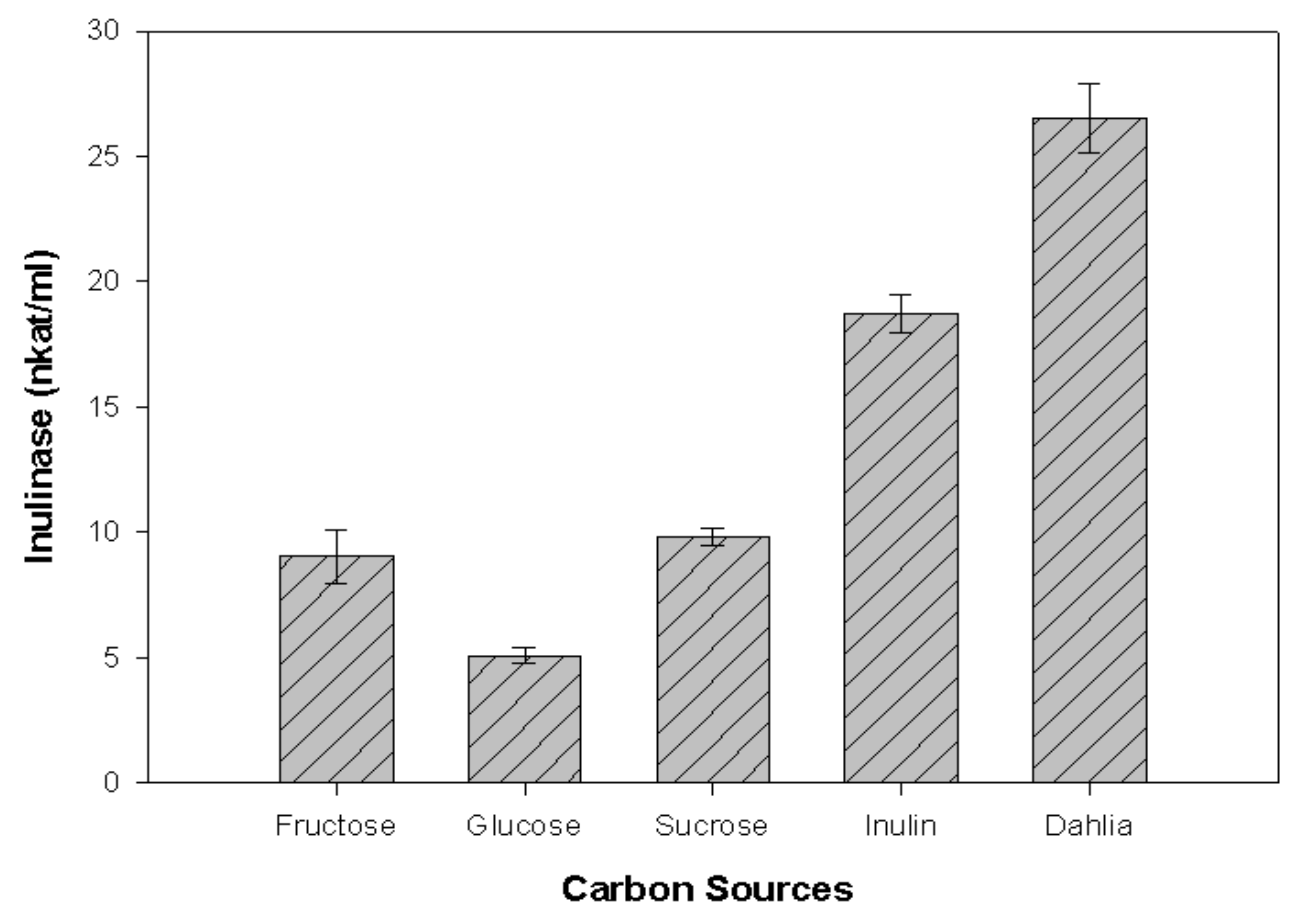

Figure 1. Effect of carbon source on inulinase production by K. marxianus MTCC 3995.

Culture condition: $28^{\circ} \mathrm{C}, 120 \mathrm{rpm}$; $96 \mathrm{~h}$. Results represent mean \pm S.D. of three experiments.

Many microbial preparations of inulinase possess remarkable invertase activity accompanying the inulinase activity. Their catalytic activity is described in terms of I/S ratio which represents ratio of the activity of enzyme preparation on inulin and sucrose (22). Almost similar I/S ratios (0.02) were observed on all the carbon sources. This indicated a direct corresponding relationship between sucrase (invertase) and inulinase activity (Table 1). Large variation in
$\mathrm{I} / \mathrm{S}$ ratios has been noticed in case of $A$. niger grown on various C-sources (6). The ratios in the range of 0.02-7.9 have been reported in literature (11).

Furthermore, with all the substrates, maximum inulinase activity was obtained on the fourth day of cultivation and dahlia extract with a $\mathrm{pH}$ shift from 6.3 to 8.2 , on dahlia -yeast extract medium (Figure 2). The optimum $\mathrm{pH}$ for inulinase activity was found to be 4.0 (Figure 3). Optimal pH 4.0 has 
also been reported for inulinase activity from Kluyveromyces marxianus var. bulgaricus (1). Inulinase of Kluyveromyces sp. Y-85 had optimum pH 4.5 (25). Pessoa and Vitolo (15) have found for $K$. marxianus inulinase optimum pH between 3.2 and
5.0 for inulinase. Kushi et al. (8) found optimum pH 4.7 for $K$. marxianus var. bulgaricus. K. marxianus inulinase showed optimal activity at $50^{\circ} \mathrm{C}$ (Figure 4). Temperature optima of $50^{\circ} \mathrm{C}$ have also been reported for $K$. marxainus $(4,25)$.

Table 1. Relationship between inulinase and invertase activity.

\begin{tabular}{lccc}
\hline Carbon source & Inulinase $\left(\right.$ nkat $\left.\mathbf{~ m L}^{-\mathbf{1}}\right)$ & Invertase $\left(\mathbf{n k a t} \mathbf{~ m L}^{\mathbf{- 1}}\right)$ & I/S \\
\hline Fructose & $8.67 \pm 1.069$ & $353.91 \pm 0.927$ & 0.024 \\
Glucose & $4.80 \pm 0.313$ & $227.63 \pm 0.819$ & 0.021 \\
Sucrose & $9.67 \pm 0.344$ & $432.17 \pm 1.023$ & 0.022 \\
Inulin & $17.86 \pm 0.769$ & $880.09 \pm 1.291$ & 0.020 \\
Dahlia & $25.30 \pm 1.384$ & $945.95 \pm 1.198$ & 0.027 \\
\hline
\end{tabular}

Results represent mean \pm S.D. of three experiments.

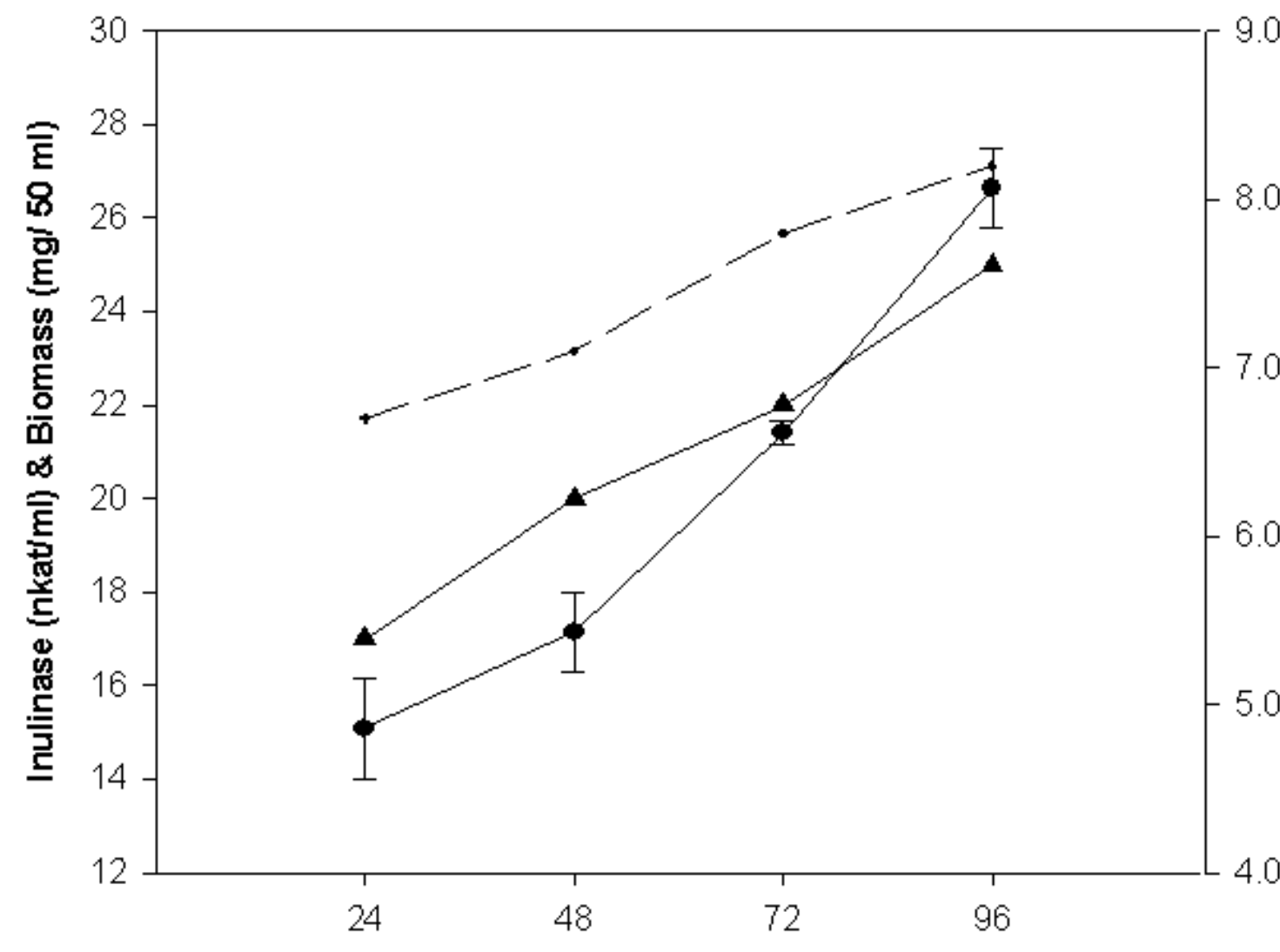

Time (hrs)

Figure 2. Production of inulinase by K. marxianus MTCC 3995 on dahlia yeast extract medium. Inulinase (•), pH (- -) and biomass $(\mathbf{\Delta})$. Results represent average of three independent experiments. 


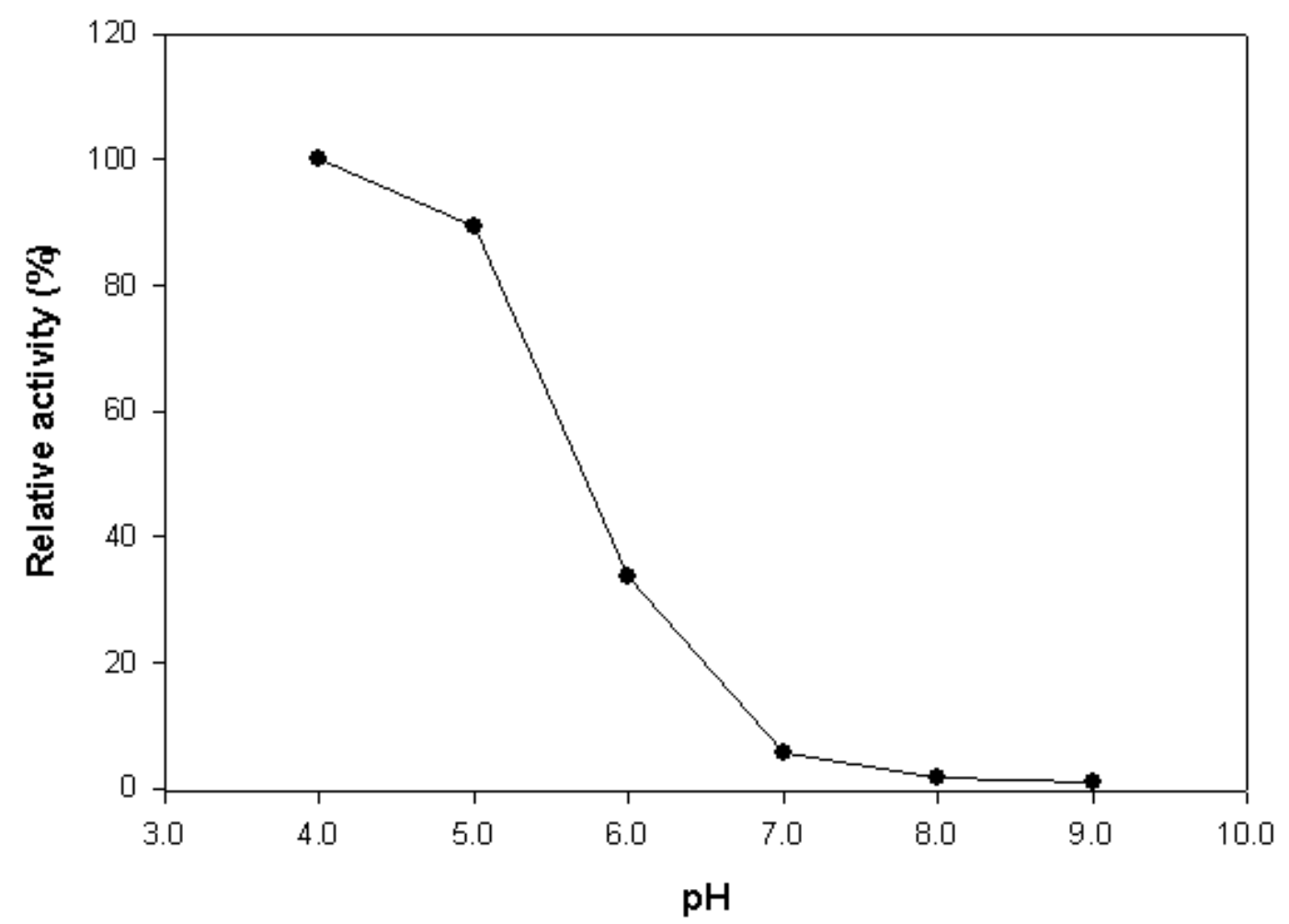

Figure 3. Effect of pH on activity of inulinase of K. Marxianus MTCC 3995.

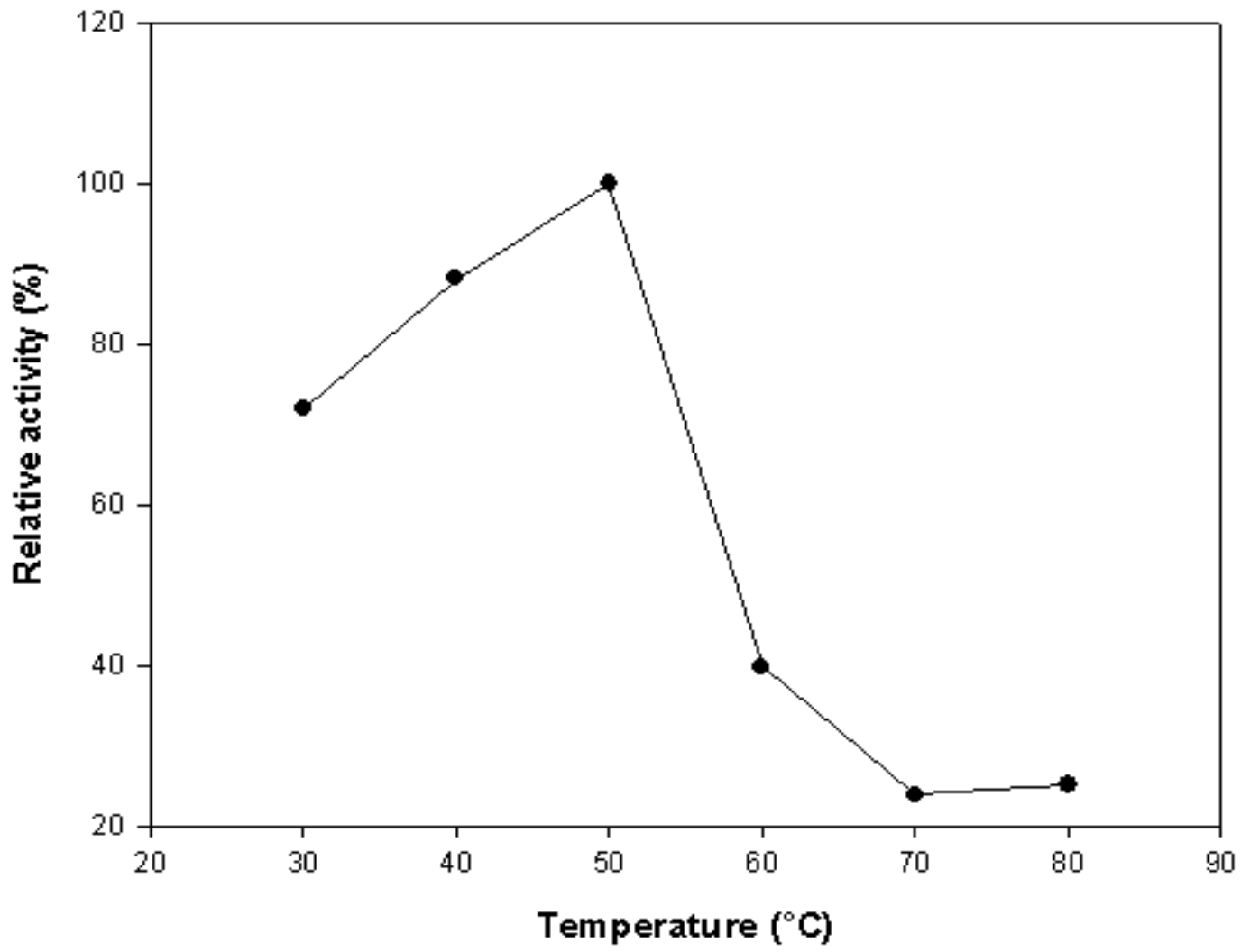

Figure 4. Effect of temperature on activity of inulinase of K. Marxianus MTCC 3995. 
Yeast extract was found to be the best nitrogen source to be used in conjunction with dahlia extract for inulinase production followed by beef extract (Figure 5). Complex nitrogen sources were better than inorganic nitrogen sources. Kango (6) also found yeast extract to be the best $\mathrm{N}$-source in media containing dandelion roots. While meat extract (21) and corn steep liquor (23) have also been reported to be better $\mathrm{N}$-source.

Thin layer chromatography was used for qualitative analysis of the products of inulinase action. Inulinases obtained from various medium showed liberation of fructose from chicory inulin indicating only exoinulinase activity (Figure 6). In the present study we have found that crude Dahlia extract can be used as a low-value substrate for production of exoinulinase using $K$. marxianus MTCC 3995. Inulinase thus produced is optimally active at $\mathrm{pH} 4.0$ and $50^{\circ} \mathrm{C}$ and liberates fructose from inulin. There seems to be a direct relationship between inulinase and invertase activities as similar I/S ratios were observed on different $\mathrm{C}$ sources.

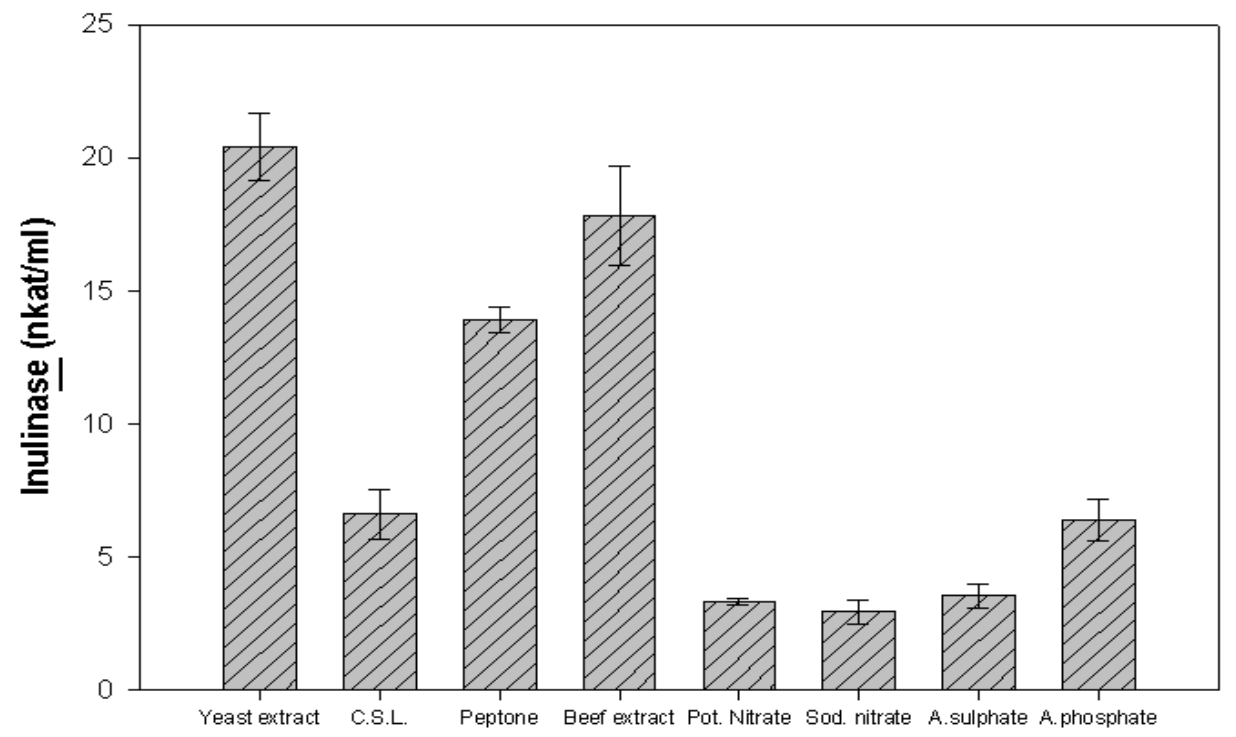

Nitrogen Sources

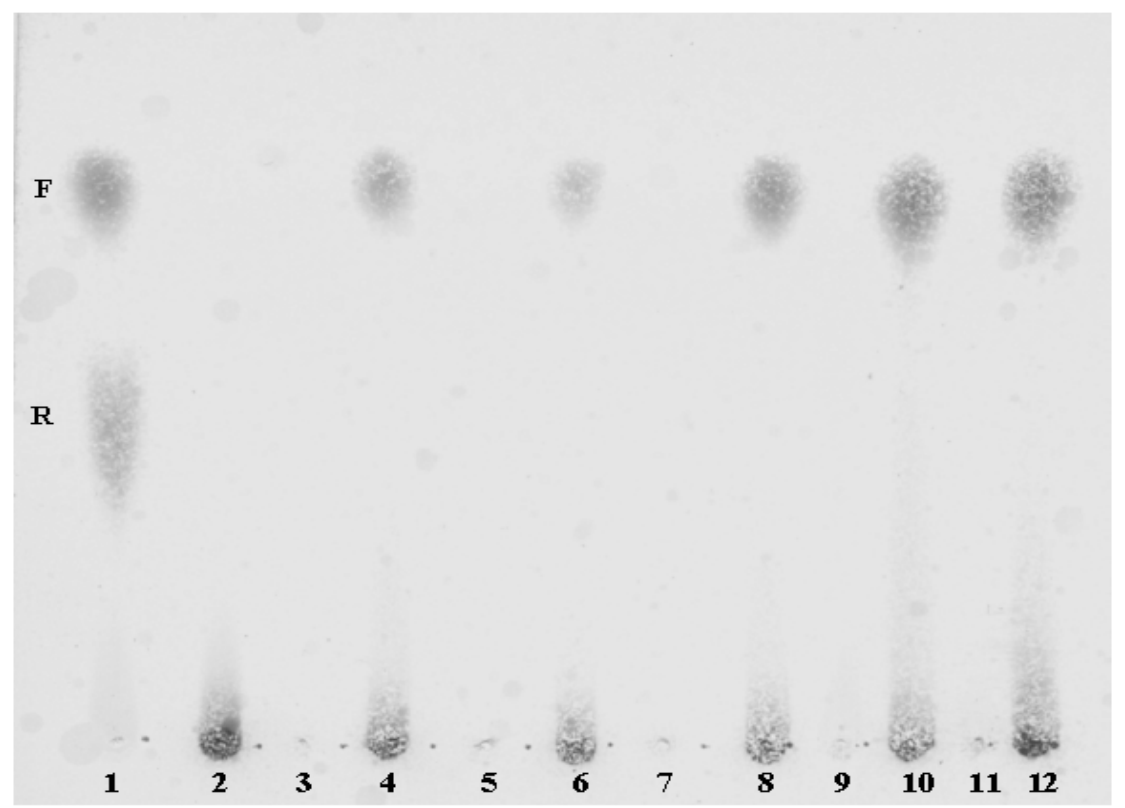

Figure 5. Effect of carbon source on inulinase production by K. marxianus MTCC 3995. Media contained dahlia extract $(20 \% \mathrm{w} / \mathrm{v})+$ nitrogen source $(2 \% \mathrm{w} / \mathrm{v})$. Results represent mean \pm S.D. of three experiments.

Figure 6. Induction of inulinase activity by different carbon sources.

Line1: Standards (F-Fructose, R-Raffinose), Line 2: Chicory Inulin; Line 3, 5, 7, 9 and 11 culture filtrates of $K$. marxianus MTCC 3995 grown on fructose, glucose, sucrose, inulin and dahlia extract media. Line 4, 6, 8, 10, and 12 end product of inulinase activity in the respective culture filtrates. 


\section{ACKNOWLEDGEMENTS}

Authors are thankful to University Grants Commission, New Delhi and MPCST, Bhopal for financial assistance. SCJ is thankful to MPCST, Bhopal for project fellowship.

\section{REFERENCES}

1. Cazetta, M.L.; Martins, P.M.M.; Monti, R.; Contiero, J. (2005). Yacon (Polymnia sanchifolia) extract as a substrate to produce inulinase by Kluyveromyces marxianus var. bulgaricus. J. Food Eng. 66, 301-305.

2. Cazetta, M.L; Monti, R.; Contiero, J. (2010). Effects of culture conditions on the Production of Inulinase by Kluyveromyces marxianus. Braz. Arch. Biol. Technol. 53 701-707.

3. Cruz, V.A.; Belote, J.G.; Belline, M.Z.; Cruz, R. (1998). Production and action pattern of inulinase from Aspergillus niger-245: Hydrolysis of inulin from several sources. Revista de Microbiol. 29, 301-306.

4. Cruz-Guerrero, A.; Garcia-Pera, I.; Barzana, E.; Garcia-Garibay, M.; Gomez-Ruiz, L. (1999). Kluyveromyces marxianus CDBB-L-278: A wild inulinase hyperproducing strain. J. Fermen. and Bioeng. 80, 159163.

5. Golunski, S.; Astolfi, V.; Carniel, N.; de Oliveira, D.; Luccio, M.D.; Mazutti, M.A.; Treichel, H. (2011). Ethanol precipitation and ultrafiltration of inulinases from Kluyveromyces marxianus. Sep. Purif. Technol.78, 261-265.

6. Kango, N. (2008). Production of inulinase using tap roots of dandelion (Taraxacum officinale) by Aspergillus niger. J. Food Eng. 85, 473-478.

7. Kango, N.; Jain, S.C. (2011). Production and properties of microbial inulinases: Recent advances. Food Biotechnol. 25 (3): 165-212.

8. Kushi, R.T.; Monti, R.; Contiero, J. (2000). Production, purification and characterization of an extracellular inulinase from Kluyveromyces marxianus var. bulgaricus. J. Ind. Microbiol. Biotechnol. 25, 63-69.

9. Mazutti, M.A.; Zabot, G.; Boni, G.; Skovronski, A.; de Oliveira, D.; Luccio, M.D.; Rodrigues, M.I.; Treichel, H.; Maugeri, F. (2010). Optimization of inulinase production by solid-state fermentation in a packed-bed bioreactor. J. Chem. Technol. Biotechnol. 85, 109-114

10. Miller, G.L. (1959). Use of dinitrosalicylic acid reagent for determination of reducing sugars. Anal. Chem. 31, 426-428

11. Moriyama, S.; Akimoto, H.; Suetsugu, N.; Kawasaki, S.; Nakamura, T.; Ohta, K. (2002). Purification and properties of an exoinulinase from Penicillium sp. strain TN-88 and sequence analysis of the encoding gene. Biosci. Biotechnol. Biochem. 66, 1887-1896.
12. Pandey, A.; Soccol, C.R.; Selvakumar, P.; Soccol, V.T.; Krieger, N.; Fontana, J.D. (1999). Recent developments in microbial inulinases: its production, properties and industrial applications. Appl. Biochem. Biotechnol. 81, 35-52.

13. Parekh, S.; Margaritis, A. (1985). Inulinase (fructofuranosidase) production by Kluyveromyces marxianus in batch culture. Appl. Microbiol Biotechnol. 22, 446- 448.

14. Park, J.P.; Yun, J.W. (2001). Utilization of chicory roots for microbial endoinulinase production. Lett. Appl. Microbiol. 33, 183-187.

15. Pessoa, A.Jr.; Vitolo, M. (1999). Inulinase from Kluyveromyces marxianus: culture medium composition and enzyme extraction. Braz. J. Chemical Eng. 16, 1-14.

16. Risso, F.V.A.; Mazutti, M.A.; Costa, F.; Treichel, H. Maugeri, F.; Rodrigues, M.I. (2010). Comparative studies of the stability of free and immobilized inulinase from Kluyveromyces marxianus NRRL Y-7571in aqueous-organic solutions. Braz. J. Chem. Eng. 27: 507-516.

17. Rodrigues, M.I.; Treichel, H.; Maugeri, F. (2010). Optimization of inulinase production by solid-state fermentation in a packed-bed bioreactor. J. Chem. Technol. Biotechnol. 85, 109-114.

18. Sharma, A. D.; Kainth, S.; Gill, P. K. (2006). Inulinase production using garlic (Allium sativum) powder as a potential substrate in Streptomyces sp. J. Food Eng. 77, 486-491.

19. Singh, P.; Gill, P.K. (2006). Production of inulinases: recent advances. Food Technol. Biotechnol. 44, 151-162.

20. Singh, R.S.; Bhermi, H.K. (2008). Production of extracellular exoinulinase from Kluyveromyces marxianus YS-1 using root tubers of Asparagus officinalis. Biores. Technol. 99, 7418-7423.

21. Singh, R.S.; Sooch, B.S.; Puri M. (2007).Optimization of medium and process parameters for the production of inulinase from a newly isolated Kluyveromyces marxianus YS-1. Biores. Technol. 98, 2518-2525.

22. Vandamme, E. J.; Derycke, D. G. (1983). Microbial inulinases: Fermentation process, properties and applications. Adv. Appl. Microbiol. 29, 139-176.

23. Viswanathan, P.; Kulkarni, P. R. (1995). Saussurea lappa (kuth) as a new source of inulin for fermentative production of inulinase in a laboratory stirred fermenter. Bioresource Technol. 52, 181-184.

24. Vranesic, D.; Kurtanjek, Z.; Santos, A.M.P.; Maugeri, F. (2002). Optimization of inulinase production by Kluyveromyces bulgaricus. Food Technol. and Biotechnol. 40, 67-73.

25. Wenling, W.; Huiying, W.W.L.; Shiyuan, W. (1999). Continuous preparation of fructose syrups from Jerusalem artichoke tuber using immobilized intracellular inulinase from Kluyveromyces sp. Y-85. Process Biochem. 34, 643-646. 